\title{
Cytotoxic immune responses in the lungs correlate to disease severity in patients with hantavirus infection
}

\author{
J. Rasmuson ${ }^{1}$ - J. Pourazar ${ }^{2}$ N. Mohamed ${ }^{3}$ - K. Lejon ${ }^{4} \cdot$ M. Evander ${ }^{3}$ - A. Blomberg ${ }^{2}$ • \\ C. Ahlm ${ }^{1}$
}

Received: 25 November 2015 / Accepted: 19 January 2016 / Published online: 12 February 2016

(C) The Author(s) 2016. This article is published with open access at Springerlink.com

\begin{abstract}
Hantavirus infections may cause severe and sometime life-threatening lung failure. The pathogenesis is not fully known and there is an urgent need for effective treatment. We aimed to investigate the association between pulmonary viral load and immune responses, and their relation to disease severity. Bronchoscopy with sampling of bronchoalveolar lavage (BAL) fluid was performed in 17 patients with acute Puumala hantavirus infection and 16 healthy volunteers acting as controls. Lymphocyte subsets, granzyme concentrations, and viral load were determined by flow cytometry, enzymelinked immunosorbent assay (ELISA), and quantitative reverse transcription polymerase chain reaction (RT-PCR), respectively. Analyses of BAL fluid revealed significantly higher numbers of activated $\mathrm{CD} 8^{+} \mathrm{T}$ cells and natural killer (NK) cells, as well as higher concentrations of the cytotoxins granzymes A and B in hantavirus-infected patients, compared to controls. In patients, Puumala hantavirus RNA was detected in $88 \%$ of BAL cell samples and correlated inversely to the T cell response. The magnitude of the pulmonary cytotoxic lymphocyte response correlated to the severity of disease and systemic organ dysfunction, in terms of need for supplemental
\end{abstract}

J. Rasmuson

johan.rasmuson@umu.se

1 Department of Clinical Microbiology, Infectious Diseases, Umeå University, 90185 Umeå, Sweden

2 Department of Public Health and Clinical Medicine, Medicine, Umeå University, Umeå, Sweden

3 Department of Clinical Microbiology, Virology, Umeå University, Umeå, Sweden

4 Department of Clinical Microbiology, Immunology, Umeå University, Umeå, Sweden oxygen treatment, hypotension, and laboratory data indicating renal failure, cardiac dysfunction, vascular leakage, and cell damage. Regulatory $\mathrm{T}$ cell numbers were significantly lower in patients compared to controls, and may reflect inadequate immune regulation during hantavirus infection. Hantavirus infection elicits a pronounced cytotoxic lymphocyte response in the lungs. The magnitude of the immune response was associated with disease severity. These results give insights into the pathogenesis and possibilities for new treatments.

\section{Introduction}

Hantaviruses are rodent-borne viruses causing disease worldwide. Infections with American hantaviruses (e.g., Andes and Sin Nombre virus) may lead to hantavirus cardiopulmonary syndrome, presenting with severe cardiopulmonary failure and high mortality, while infections with Asian or European hantaviruses are known to cause hemorrhagic fever with renal syndrome, characterized by coagulopathy and acute renal insufficiency [1-4]. The dichotomy of hantavirus syndromes is not clear cut, as patients infected with European Puumala virus (PUUV) commonly present with lung involvement, indicated by lower respiratory tract symptoms and impaired pulmonary gas diffusion capacity [5-7]. There is currently no effective treatment or vaccine.

The pathogenesis is poorly understood, but vascular dysfunction and intense cytotoxic lymphocyte responses are believed to be, at least partly, responsible for the development of disease manifestations [8-11]. Previous studies of hantavirusinfected patients have revealed expansions of cytotoxic $T$ cells (CTLs) and natural killer (NK) cells in the lungs $[5,12,13]$. The presence of virus in the lungs during hantavirus infection has only been evaluated in post-mortem samples from patients infected with American hantaviruses or in small case series of 
patients with PUUV infection [12-16]. The relationship between viral load and immune response in the lungs has never been established. We aimed to investigate the pulmonary immune response and viral load in acute hantavirus disease. We hypothesized that a cytotoxic lymphocyte response in the lungs, along with detectable viral RNA, would be associated with disease severity.

\section{Materials and methods}

\section{Patients and bronchoscopy}

We included all hospitalized hantavirus-infected patients at the Department of Infectious Diseases (University Hospital, Umeå, Sweden) during the period from January 2008 to March 2011. A total of 47 patients were admitted, but 30 did not participate due to lack of consent $(n=19)$, short hospitalization ( $<2$ days, $n=7)$, or logistical reasons $(n=4)$. Seventeen patients (11 females; median age 54 years, range $31-69$ ) with acute PUUV infection agreed to bronchoscopy. All but one of the included patients were also part of a study evaluating heart and lung manifestations [6]. One patient had allergic asthma, while the rest were previously lung-healthy. Seven patients were smokers, defined as current smoking $(n=4)$ or smoking cessation within the last two years $(n=3)$. Sixteen healthy gender-, age-, and smoking habit-matched volunteers acted as controls. The study was approved by the regional ethical review board at Umeå University (number 07-162 M). Participants were treated according to the declaration of Helsinki and all gave written informed consent.

Bronchoscopy with sampling of bronchoalveolar lavage (BAL) fluid from the right middle lobe was performed in controls and in patients 6-14 days (median 9 days) post symptom onset, as previously described [5]. To avoid bleeding complications, bronchoscopy was undertaken as soon as platelet numbers were improving and deemed sufficient $\left(>100 \times 10^{9} / \mathrm{L}\right)$.

\section{Analyses of BAL fluid}

BAL cell differential counts were performed as previously described [17]. Subsets of bronchoalveolar lymphocytes were determined by flow cytometry using the FACSCalibur system (Becton Dickinson, San Jose, CA). Cells were prepared as previously described [5] and stained with fluorochrome-conjugated monoclonal antibodies, as detailed in Table 1. CD25, CD69, HLA-DR, and NKG2D were used as markers for lymphocyte activation. Up to 80,000 total events were collected per sample.

Cytotoxic lymphocyte activity and mediators of inflammation were determined in BAL fluid supernatants using commercial enzyme-linked immunosorbent assay (ELISA) kits; for granzyme A (GzmA) (BioVendor, Brno, Czech Republic), granzyme B (GzmB) (Abcam, Cambridge, MA), and tumor necrosis factor- $\alpha$ and interleukin 6 (R\&D Systems, Abingdon, UK).

PUUV RNA was analyzed separately in bronchoalveolar cells and supernatant. Viral RNA was extracted as previously described [18], and cDNA was generated by using $5 \mu \mathrm{L}$ RNA and the GoScript ${ }^{\mathrm{TM}}$ Reverse Transcription System (Promega Biotech, CA), according to the manufacturer's instructions. Before the polymerase chain reaction (PCR) assay, cDNA was pretreated with $\mathrm{HK}^{\mathrm{TM}}$ UNG (Epicentre Technologies, Madison, WI) to ensure that any contaminating PCR products did not affect subsequent PCR. The quantitative PCR was performed in triplicate, and including negative controls [18].

\section{Indicators of disease severity}

Clinical data indicating severe disease were need for oxygen treatment, lowest recorded systolic blood pressure, and number of days in hospital. Laboratory investigations in serum or plasma included C-reactive protein, Nterminal pro-B-type natriuretic peptide (NT-proBNP), troponin $\mathrm{T}$, albumin, lactate dehydrogenase (LDH), and creatinine, along with leukocyte and platelet counts, analyzed at the hospital's accredited laboratory. Samples were taken on the day of study inclusion and then every second day throughout hospitalization, including the day of bronchoscopy.

\section{Statistical analysis}

Statistical analyses were performed using IBM SPSS Statistics (version 22) by Mann-Whitney U tests for group comparisons and Spearman's ranked correlations test for correlation analysis. All tests were two-tailed and a $p$-value $<0.05$ was considered statistically significant.

\section{Results}

\section{Clinical and laboratory findings}

The clinical characteristics and laboratory results are summarized in Table 2. Briefly, all patients displayed typical clinical presentation for PUUV infection and almost two-thirds of the patients experienced respiratory symptoms, such as dyspnea or dry cough. One-third required supplemental oxygen treatment, due to low oxygen saturation $(\leq 92 \%)$ and/or significant dyspnea and one-third showed transient hypotension (systolic blood pressure $\leq 90 \mathrm{mmHg}$ ). A majority of the patients displayed thrombocytopenia, acute renal impairment (elevated creatinine), systemic inflammation (elevated C-reactive 
Table 1 Antibodies used for flow cytometry determination of bronchoalveolar lymphocyte subsets

\begin{tabular}{|c|c|}
\hline Lymphocyte subset & Antibody ligand (fluorochrome) \\
\hline $\mathrm{T}$ cells $\left(\mathrm{CD}^{+}\right)$ & CD3 (PerCP) \\
\hline $\mathrm{T}$ helper cells $\left(\mathrm{CD}^{+} \mathrm{CD}^{+}\right)$ & CD3 (PerCP), CD4 (FITC) \\
\hline Cytotoxic $\mathrm{T}$ cells $\left(\mathrm{CD} 3^{+} \mathrm{CD} 8^{+}\right)$ & CD3 (PerCP), CD8 (PE) \\
\hline Natural killer cells $\left(\mathrm{CD} 3^{-} \mathrm{CD} 16^{+} \mathrm{CD} 56^{+}\right)$ & CD3 (FITC), CD16 (PE), CD56 (PE) \\
\hline $\begin{array}{l}\text { Regulatory T cells } \\
\quad\left(\mathrm{CD} 3^{+} \mathrm{CD} 4^{+} \mathrm{CD} 25^{\text {bright }} \mathrm{CD} 127^{\text {low } /-}\right)\end{array}$ & $\begin{array}{l}\text { CD3 (APC), CD4 (FITC), CD25 (PE-Cy5), } \\
\text { CD127 (PE) }\end{array}$ \\
\hline Activated $\mathrm{T}$ helper cells $\left(\mathrm{CD}^{+} \mathrm{CD}^{+} \mathrm{CD} 25^{+}\right)$ & CD3 (APC), CD4 (FITC), CD25 (PE) \\
\hline Activated $\mathrm{T}$ helper cells $\left(\mathrm{CD} 3^{+} \mathrm{CD} 4^{+} \mathrm{CD} 69^{+}\right)$ & CD3 (APC), CD4 (FITC), CD69 (PE) \\
\hline Activated $\mathrm{T}$ helper cells $\left(\mathrm{CD}^{+}{ }^{+} \mathrm{CD} 4^{+} \mathrm{HLA}^{-\mathrm{DR}^{+}}\right)$ & CD3 (APC), CD4 (FITC), HLA-DR (PE) \\
\hline Activated cytotoxic $\mathrm{T}$ cells $\left(\mathrm{CD} 3^{+} \mathrm{CD} 8^{+} \mathrm{CD} 25^{+}\right)$ & CD3 (APC), CD8 (PerCP), CD25 (PE) \\
\hline Activated cytotoxic T cells $\left(\mathrm{CD} 3^{+} \mathrm{CD} 8^{+} \mathrm{CD} 69^{+}\right)$ & CD3 (APC), CD8 (PerCP), CD69 (PE) \\
\hline Activated cytotoxic $\mathrm{T}$ cells $\left(\mathrm{CD} 3^{+} \mathrm{CD} 8^{+} \mathrm{HLA}-\mathrm{DR}^{+}\right)$ & CD3 (APC), CD8 (PerCP), HLA-DR (PE) \\
\hline Activated cytotoxic T cells $\left(\mathrm{CD}^{+}{ }^{+} \mathrm{CD} 8^{+} \mathrm{NKG}^{-} \mathrm{D}^{+}\right)$ & CD3 (PerCP), CD8 (FITC), NKG2D (PE) \\
\hline \multicolumn{2}{|c|}{$\begin{array}{l}A P C \text { allophycocyanin; } F I T C \text { fluorescein isothiocyanate; } P E \text { phycoerythrin; } P E-C y 5 \text { phycoerythrin-Cy } 5 ; \operatorname{Per} C P \\
\text { peridinin chlorophyll protein }\end{array}$} \\
\hline \multicolumn{2}{|c|}{$\begin{array}{l}\text { Antibody clones used were: SK7 (anti-CD3); SK3 (anti-CD4); SK1 (anti-CD8); B73 (anti-CD16); MY31 (anti- } \\
\text { CD56); 2A3 (anti-CD25 PE); L78 (anti-CD69); L243 (anti-HLA-DR); 1D11 (anti-NKG2D); BC96 (anti-CD25 } \\
\text { PE-Cy5); hIL-7R-M21 (anti-CD127). All antibodies were purchased from Becton Dickinson (San Jose, CA), } \\
\text { except anti-CD25 PE-Cy5 (BioLegend, San Diego, CA) }\end{array}$} \\
\hline
\end{tabular}

protein and leukocytosis), and increased LDH indicating cell damage (Table 2). Albumin concentrations were low, suggesting vascular leakage (Table 2), and were correlated with patients' lowest recorded systolic blood pressure $(r=0.61$, $p=0.009)$. Patients requiring oxygen treatment had significantly lower albumin and trends towards higher creatinine

Table 2 Clinical characteristics and laboratory results in patients with Puumala hantavirus infection

\begin{tabular}{ll}
\hline $\begin{array}{l}\text { Days of hospitalization } \\
\text { Clinical findings }\end{array}$ & $5(2-9)$ \\
Hypotension $(\leq 90 \mathrm{mmHg})$ & $6(35 \%)$ \\
Respiratory symptoms & $10(59 \%)$ \\
Dyspnea & $8(47 \%)$ \\
Dry cough & $5(29 \%)$ \\
Oxygen treated & $5(29 \%)$ \\
Laboratory results & \\
Leukocyte count $\left(3.5-8.8 \times 10^{9} / \mathrm{L}\right), \max$ & $9.0(5.3-27.0)$ \\
C-reactive protein $(<3 \mathrm{mg} / \mathrm{L}), \max$ & $78(35-249)$ \\
Platelet count $\left(145-387 \times 10^{9} / \mathrm{L}\right), \min$ & $63(18-305)$ \\
Creatinine $(<105 \mu \mathrm{mol} / \mathrm{L}), \max$ & $173(59-1072)$ \\
Lactate dehydrogenase $(<3.4 \mu \mathrm{kat} / \mathrm{L}), \max$ & $4.8(3.8-12.3)$ \\
Albumin $(36-45 \mathrm{~g} / \mathrm{L}), \min$ & $28(14-34)$ \\
NT-proBNP $(<150 \mathrm{ng} / \mathrm{L}), \max$ & $1768(121-8878)$ \\
Troponin $\mathrm{T}(<15 \mathrm{ng} / \mathrm{L}), \max$ & $8(0-22)$ \\
\hline
\end{tabular}

NT-proBNP N-terminal pro-B-type natriuretic peptide

Clinical findings are presented as number of patients (\%) with the respective finding, while blood laboratory results (reference values) and numbers of days of hospitalization are expressed as median (range) and leukocyte counts (Table 3 ) compared to those not needing oxygen. No patient required dialysis and all survived.

\section{Cytotoxic responses in the lungs}

Higher lymphocyte numbers were found in patients compared to controls (Table 4). The flow cytometry results revealed an inversed bronchoalveolar CD4/CD8 $\mathrm{T}$ cell ratio in patients, due to expansions of the $\mathrm{CD} 8^{+}$cytotoxic subset, also showing strong activation mainly in terms of frequent HLA-DR and NKG2D expression (Fig. 1). The lymphocyte expansion was, considering absolute numbers, further explained by significantly higher numbers of CTLs and NK cells in patients compared to controls, while the numbers of $\mathrm{CD}^{+} \mathrm{T}$ helper (Th) cells were similar (Table 4). The numbers of CTLs expressing activation markers CD25, CD69, HLA-DR, or NKG2D were significantly higher in patients, while no such activation was seen in the Th subset in either relative or absolute numbers (Table 4 and data not shown). Regulatory T (Treg) cells were significantly fewer in patients (Table 4). Although Tregs were few, their number in patients (but not in controls) were significantly correlated to the number of T cells, Th cells, CTLs, and activated CTLs (data not shown), suggesting that stronger T cell responses proportionally also included Tregs. Serum LDH concentration on the day of bronchoscopy correlated to the magnitude of the immune response detected in BAL fluid, expressed as numbers of lymphocytes $(r=0.66, p=0.004)$, T cells $(r=0.73, p=0.001)$, CTLs $(r=0.82, p<0.001)$, and HLA-DR ${ }^{+}$CTLs $(r=0.67, p=0.007)$.

Compared to controls, hantavirus-infected patients had significantly higher BAL fluid concentrations of GzmA and 
Table 3 Differences in parameters comparing patients with or without need for supplemental oxygen treatment

\begin{tabular}{|c|c|c|c|}
\hline & $\begin{array}{l}\text { Oxygen } \\
\text { treatment }(n=5)\end{array}$ & $\begin{array}{l}\text { No oxygen } \\
\text { treatment }(n=12)\end{array}$ & $\begin{array}{l}p \text { - } \\
\text { Value }\end{array}$ \\
\hline \multicolumn{4}{|l|}{ Laboratory results } \\
\hline Leukocyte count $\left(10^{9} / \mathrm{L}\right)$, max & $15.1(9.1-15.8)$ & $8.6(7.0-9.5)$ & 0.058 \\
\hline C-reactive protein $(\mathrm{mg} / \mathrm{L}), \max$ & $187(65-203)$ & $73(37-128)$ & 0.11 \\
\hline Platelet count $\left(10^{9} / \mathrm{L}\right)$, min & $63(42-85)$ & $63(42-90)$ & 1.00 \\
\hline Creatinine $(\mu \mathrm{mol} / \mathrm{L}), \max$ & $276(186-327)$ & $130(83-219)$ & 0.058 \\
\hline $\begin{array}{l}\text { Lactate dehydrogenase }(\mu \mathrm{kat} / \mathrm{L}) \text {, } \\
\max \end{array}$ & $4.9(4.6-6.2)$ & $4.5(4.2-5.1)$ & 0.21 \\
\hline Albumin $(g / L), \min$ & $22(17-27)$ & $29(24-31)$ & 0.034 \\
\hline NT-proBNP (ng/L), max & $2342(1419-6862)$ & $728(523-4393)$ & 0.17 \\
\hline Troponin T (ng/L), max & $10(7-19)$ & $8(0-11)$ & 0.22 \\
\hline \multicolumn{4}{|l|}{ Differential cell counts } \\
\hline Macrophages & $22.0(17.1-44.3)$ & $15.0(11.4-30.2)$ & 0.21 \\
\hline Eosinophils & $0.1(0-0.2)$ & $0(0-0.8)$ & 0.21 \\
\hline Neutrophils & $0.6(0.5-0.7)$ & $0.4(0.2-0.6)$ & 0.14 \\
\hline Lymphocytes & $9.9(6.2-15.7)$ & $3.2(2.0-7.7)$ & 0.015 \\
\hline \multicolumn{4}{|l|}{ Flow cytometry } \\
\hline $\mathrm{T}$ cells & $9.5(5.6-14.9)$ & $2.6(1.5-7.5)$ & 0.020 \\
\hline $\mathrm{T}$ helper cells & $1.9(1.7-5.2)$ & $0.6(0.3-2.7)$ & 0.079 \\
\hline Cytotoxic T cells & $7.3(3.5-9.3)$ & $1.4(1.1-4.8)$ & 0.036 \\
\hline Natural killer cells & $0.5(0.4-0.6)$ & $0.2(0.1-0.5)$ & 0.10 \\
\hline Regulatory T cells & $0.6(0.4-1.5)$ & $0.4(0.2-0.7)$ & 0.19 \\
\hline $\mathrm{T}$ helper cells, $\mathrm{CD} 25^{+}$ & $0.1(0.1-0.2)$ & $0(0-0.1)$ & 0.047 \\
\hline T helper cells, $\mathrm{CD} 69^{+}$ & $0(0-0)$ & $0(0-0.3)$ & 0.82 \\
\hline $\mathrm{T}$ helper cells, HLA-DR ${ }^{+}$ & $0.5(0.3-1.3)$ & $0.1(0.1-0.4)$ & 0.066 \\
\hline Cytotoxic T cells, CD25 $5^{+}$ & $0.1(0-0.5)$ & $0.1(0-0.1)$ & 0.40 \\
\hline Cytotoxic T cells, $\mathrm{CD} 9^{+}$ & $0(0-0.2)$ & $0.1(0-0.2)$ & 0.96 \\
\hline Cytotoxic T cells, HLA-DR ${ }^{+}$ & $3.6(1.5-4.1)$ & $0.9(0.4-2.9)$ & 0.11 \\
\hline Cytotoxic T cells, NKG2D ${ }^{+}$ & $2.6(1.0-4.3)$ & $0.6(0-1.0)$ & 0.020 \\
\hline \multicolumn{4}{|l|}{ Granzymes and cytokines } \\
\hline Granzyme A & $326(104-643)$ & $255(116-509)$ & 0.83 \\
\hline Granzyme B & $33(6-84)$ & $5(0-23)$ & 0.070 \\
\hline Interleukin 6 & $0.8(0.7-1.8)$ & $0.9(0.6-1.5)$ & 0.83 \\
\hline Tumor necrosis factor- $\alpha$ & $0(0-0)$ & $0(0-0.6)$ & 0.24 \\
\hline Viral load & $\begin{array}{l}1.4 \times 10^{1}\left(0.2 \times 10^{1} \text { to }\right. \\
\left.\quad 6.2 \times 10^{5}\right)\end{array}$ & $\begin{array}{l}3.0 \times 10^{3}\left(1.2 \times 10^{1} \text { to }\right. \\
\left.1.5 \times 10^{4}\right)\end{array}$ & 0.40 \\
\hline
\end{tabular}

Results are expressed as median (25th-75th percentiles). Laboratory results were obtained by analyses on blood, serum, or plasma. Bronchoalveolar lavage fluid results represent: cells per $\mathrm{mL} \times 10^{4}\left(\times 10^{2}\right.$ for regulatory T cells $)$, pg of granzymes and cytokines per mL, and copy numbers of Puumala virus RNA per $10^{4}$ bronchoalveolar cells. $p$-Values were determined by the Mann-Whitney $\mathrm{U}$ test
GzmB (Table 4), and the two cytotoxins' levels were correlated $(r=0.49, p=0.044)$. The GzmA and GzmB concentrations in BAL fluid from patients correlated to the numbers of bronchoalveolar lymphocytes $(r=0.49, p=0.048$ and $r=0.57$, $p=0.016$, respectively), $\mathrm{T}$ cells $(r=0.53, p=0.035$ and $r=0.62, p=0.011$, respectively), CTLs $(r=0.58, p=0.018$ and $r=0.52, p=0.041$, respectively), and HLA-DR ${ }^{+}$CTLs ( $r=0.62, p=0.013$ and $r=0.61, p=0.016$, respectively). Additionally, GzmB concentrations correlated to the numbers of $\mathrm{NKG}_{2} \mathrm{D}^{+}$CTLs $(r=0.68, p=0.004)$. The GzmA concentration in BAL fluid correlated to bronchoscopy-day serum LDH $(r=0.54, p=0.025)$. Interleukin 6 and tumor necrosis factor- $\alpha$ levels in BAL fluid did not differ between patients and controls (Table 4).

\section{Pulmonary viral load}

PUUV RNA could be demonstrated in bronchoalveolar cells in 15 out of 17 (88\%) patients. Four patients also had detectable PUUV RNA in BAL supernatant. When 
Table 4 Bronchoalveolar immune responses in patients versus healthy controls

\begin{tabular}{|c|c|c|c|}
\hline & Patients $(n=17)$ & Controls $(n=16)$ & $p$-Value \\
\hline Return volume & $95.0(81.0-119.0)$ & $108.0(67.5-123.0)$ & 0.86 \\
\hline \multicolumn{4}{|l|}{ Differential cell counts } \\
\hline Macrophages & $16.8(11.7-33.5)$ & $20.5(13.4-32.1)$ & 0.67 \\
\hline Neutrophils & $0.5(0.2-0.6)$ & $0.2(0.0-0.4)$ & 0.088 \\
\hline Eosinophils & $0.00(0.00-0.11)$ & $0.05(0.00-0.28)$ & 0.40 \\
\hline Lymphocytes & $4.2(2.1-9.3)$ & $1.8(1.2-2.5)$ & 0.001 \\
\hline \multicolumn{4}{|l|}{ Flow cytometry } \\
\hline T cells & $4.3(1.9-9.1)$ & $1.5(1.1-1.8)$ & 0.002 \\
\hline T helper cells & $1.3(0.4-2.5)$ & $1.0(0.6-1.5)$ & 0.71 \\
\hline Cytotoxic T cells & $2.6(1.1-6.4)$ & $0.3(0.1-0.6)$ & $<0.001$ \\
\hline Natural killer cells & $0.08(0.05-0.11)$ & $0.04(0.02-0.07)$ & 0.034 \\
\hline Regulatory T cells & $0.42(0.22-0.80)$ & $1.38(0.77-3.14)$ & 0.004 \\
\hline $\mathrm{T}$ helper cells, $\mathrm{CD} 69^{+}$ & $0.02(0.00-0.04)$ & $0.01(0.00-0.07)$ & 0.62 \\
\hline T helper cells, HLA-DR ${ }^{+}$ & $0.23(0.06-0.59)$ & $0.20(0.12-0.32)$ & 0.46 \\
\hline $\mathrm{T}$ helper cells, $\mathrm{CD} 25^{+}$ & $0.06(0.02-0.14)$ & $0.06(0.02-0.14)$ & 0.80 \\
\hline Cytotoxic T cells, CD25 $5^{+}$ & $0.06(0.02-0.19)$ & $0.00(0.00-0.01)$ & $<0.001$ \\
\hline Cytotoxic T cells, CD69 ${ }^{+}$ & $0.05(0.01-0.16)$ & $0.01(0.00-0.03)$ & 0.046 \\
\hline Cytotoxic T cells, HLA-DR ${ }^{+}$ & $1.14(0.46-3.12)$ & $0.03(0.01-0.06)$ & $<0.001$ \\
\hline Cytotoxic T cells, NKG2D ${ }^{+}$ & $0.80(0.06-2.11)$ & $0.04(0.01-0.05)$ & 0.001 \\
\hline \multicolumn{4}{|l|}{ Granzymes and cytokines $^{\mathrm{a}}$} \\
\hline Granzyme A & $287.5(126.3-484.5)$ & $19.7(13.7-59.4)$ & $<0.001$ \\
\hline Granzyme B & $6.3(0-30.4)$ & $0(0-0)$ & $<0.001$ \\
\hline Interleukin 6 & $0.8(0.7-1.5)$ & $1.6(0.9-2.1)$ & 0.08 \\
\hline Tumor necrosis factor- $\alpha$ & $0(0-0)$ & $0(0-0)$ & 0.61 \\
\hline
\end{tabular}

Results are presented as median (25th-75th percentiles) and represent the number of cells per $\mathrm{mL} \times 10^{4}\left(\times 10^{2}\right.$ for regulatory T cells) or pg of granzymes and cytokines per $\mathrm{mL}$ of bronchoalveolar lavage fluid. $p$-Values were determined by the Mann-Whitney U test

${ }^{\text {a }}$ Number of subjects with detectable levels; granzyme A (all subjects), granzyme B (12 patients and one control), interleukin 6 (all subjects), tumor necrosis factor- $\alpha$ (three patients and two controls) considering positive samples, the median $(25$ th-75th percentiles) viral load was $3.9 \times 10^{2}\left(1.4 \times 10^{1}\right.$ to $\left.1.8 \times 10^{4}\right)$ PUUV RNA copies per $10^{4}$ bronchoalveolar cells and $4.4 \times 10^{3}\left(1.8 \times 10^{3}\right.$ to $\left.2.6 \times 10^{5}\right)$ copies per $\mathrm{mL}$ of supernatant. The viral load in bronchoalveolar cells was inversely correlated to the magnitude of the local immune response, in terms of the numbers of total lymphocytes $(r=-0.68, p=0.003)$, T cells $(r=-0.70, p=0.003)$, Th cells $(r=-0.71, p=0.002)$, CTLs $(r=-0.71, p=0.002)$, and HLA-DR expressing CTLs $(r=-0.58, p=0.023)$. In addition, the levels of granzymes correlated inversely to viral load, but reaching significance only for GzmA $(r=-0.69, p=0.002)$.

\section{Correlations to disease severity}

Pronounced lymphocyte responses in the lungs were found to correlate to several indicators of more severe disease, suggestively reflecting the systemic nature of hantavirus infection. Firstly, significantly higher numbers of bronchoalveolar lymphocytes, T cells, CTLs, and NKG2D ${ }^{+}$CTLs were found in patients requiring oxygen treatment compared to those without a need for supplemental oxygen (Table 3). Secondly, low systolic blood pressure was associated with an intense bronchoalveolar immune response, in terms of total lymphocytes $(r=-0.61, p=0.009)$, T cells $(r=-0.64, p=0.008), \mathrm{Th}$ cells $(r=-0.50, p=0.047)$, CTLs $(r=-0.57, p=0.022)$, and NK cells $(r=-0.58, p=0.019)$. Thirdly, high numbers of bronchoalveolar CTLs were correlated to laboratory surrogate markers of impaired renal function (maximum creatinine, $r=0.54, p=0.030$ ), cardiac dysfunction (maximum NT-proBNP, $r=0.67, p=0.004$ and maximum troponin $\mathrm{T}, r=0.41, p=0.023$ ), cell damage (maximum $\mathrm{LDH}, r=0.56, p=0.025$ ), and vascular leakage (minimum albumin, $r=-0.50, p=0.049)$. There were no significant correlations between any indicator of more severe disease and viral load, concentrations of granzymes, Treg cell numbers, or proportions of lymphocyte subsets in BAL fluid (Table 3 and data not shown). 

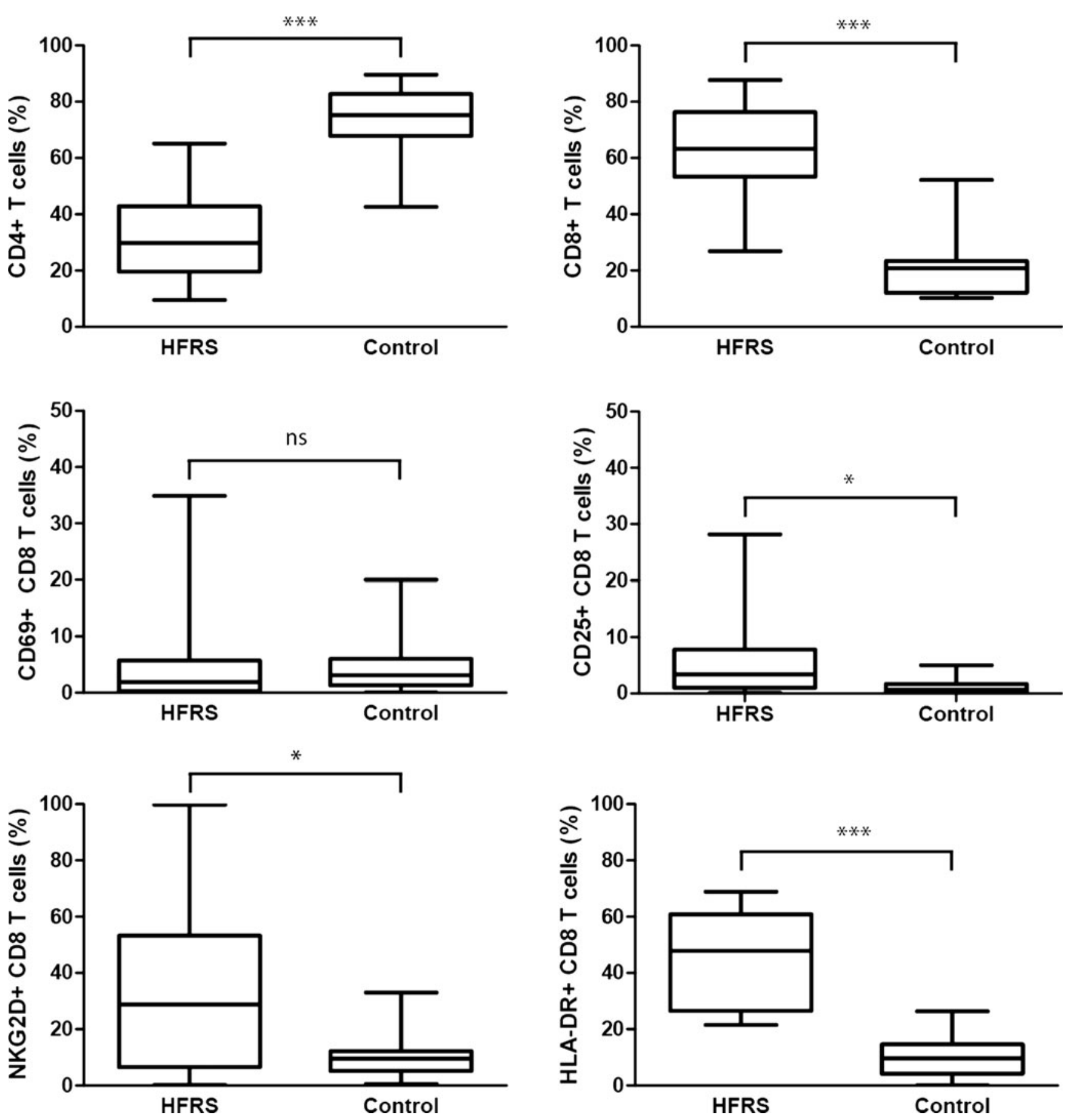

Fig. 1 Proportions of bronchoalveolar T cell subsets in patients with acute Puumala hantavirus infection compared to the uninfected healthy controls. Patients displayed an inverse CD4/CD8 T cell ratio due to expansion of the $\mathrm{CD}^{+} \mathrm{T}$ cell population. Large proportions of $\mathrm{CD} 8^{+} \mathrm{T}$ cells showed evidence of an active state in hantavirus infection, indicated

\section{Discussion}

We have demonstrated that hantavirus infection induces an activated cytotoxic effector immune response in the lungs. The magnitude of the immune response was associated with need for oxygen treatment, indicating poor

by significantly higher expression of activation markers CD69, HLA-DR, and NKG2D on $\mathrm{CD}^{+} \mathrm{T}$ cells in patients compared to the healthy controls. ${ }^{*} p<0.05,{ }^{* * *} p<0.001$ for comparisons by the Mann-Whitney $\mathrm{U}$ test, $\mathrm{ns}=$ not significant

gas exchange, as well as several systemic markers for disease severity.

Hantaviruses cause infections with varying severity of pulmonary involvement, characterized by reduced gas exchange due to interstitial or alveolar edema $[3,6]$. The immune response, including cytotoxic lymphocytes 
(CTLs and NK cells), has been considered to be at least partly responsible for the development of hantavirus disease manifestations [8-11]. Here, expansions of CTLs and NK cells were detected in the lungs of hantavirus-infected patients, as previously reported $[5,12,13,19]$. The high expression of activation markers on CTLs in hantavirus infection corroborates with previous studies $[5,10]$ and indicates an activated effector state in these cells [20]. Interestingly, CTLs were not required to cause severe disease in a hamster model for lethal Andes hantavirus infection [21], which could question the role of CTLs in human hantavirus pathogenesis. However, in a recently described macaque model for Sin Nombre hantavirus disease that may better mimic hantavirus infection in humans, expansion of activated CTLs in blood was reported, with the highest CTL proportions occurring during the most severe disease stage [22]. In contrast to previous studies comparing proportions of CTLs in BAL [5] or in blood [23] to disease severity, we report here high absolute CTL numbers in the lungs being associated with several indicators of more severe disease, in accordance with a previous report [9]. Moreover, our finding of higher levels of cardiac dysfunction markers in patients with intense lung immune responses may represent a further indication of secondary heart manifestations in hantavirus disease [6, 24].

Granzymes are effector molecules released from cytotoxic lymphocytes and may be used to measure cytotoxic activity [25]. GzmA and GzmB both induce apoptosis but by different mechanisms [25]. To the best of our knowledge, soluble granzymes have not been evaluated in BAL fluid in respiratory viral infections. Intracellular GzmB has been shown to be expressed in activated CTLs or NK cells in lungs in severe infant respiratory syncytial virus infection and lungs of fatal PUUV cases [12, 26], as well as in blood in human hantavirus infection $[10,27]$ and in a macaque model [22]. Furthermore, serum LDH has been shown to correlate to markers for apoptosis during hantavirus disease [28]. The high concentrations of BAL fluid GzmA and GzmB found in patients in the current study indicate cytotoxic lymphocyte degranulation within the airways, likely reflecting the killing of hantavirus-infected cells within the airways (immune cells or bronchial epithelial cells). In support of this scenario, we report that bronchoalveolar CTLs, granzymes, viral load, and serum LDH were all significantly correlated. However, a demonstrated hantavirusconferred resistance to apoptosis of infected cells, with an inability at least for NK cells to clear virus-infected cells, could lead to uninfected bystander cell death, protracted cytotoxic immune responses, and excessive immunopathology [27, 29].

Regulatory $\mathrm{T}$ cells are important regulators of the immune system and function to achieve balanced effector responses that clear pathogens without causing excessive immunopathology [30]. High numbers of Treg cells have been shown to maintain persistence and avoid immunopathology in various chronic viral infections, including hantavirus infection in the natural rodent host [31], but little is yet known when it comes to Treg responses in acute human viral infections [30]. Low Treg levels have been proposed to be responsible for the development of West Nile fever [32], severe dengue [33, 34], as well as hantavirus disease in humans [35]. Accordingly, we report bronchoalveolar Tregs being significantly fewer in hantavirus-infected patients compared to controls, suggesting an inadequate Treg cell response, as previously shown in blood in human hantavirus infection [10,36], as well as in the lungs in the lethal hamster model [37]. A recent study of human hantavirus infection showed that high blood leukocyte count, as well as the level of Treg cell activity, was associated with some markers for disease severity [23]. Similarly, we show that the Treg cells response was proportional to the effector $\mathrm{T}$ cell response, even if the Tregs numbers were low and possibly inadequate to maintain balance, leading to overly strong effector $\mathrm{T}$ cell responses [35]. Taken together, the importance and function of Treg cells in human hantavirus infections are still poorly understood and warrant further studies.

Puumala hantavirus RNA was detected in bronchoalveolar cells in almost all patients, implying that infection of airway lumen cells is highly frequent. As expected, viral RNA was predominately found within the BAL cells. We did not determine which bronchoalveolar cells contained viral RNA. However, previous studies have shown macrophages and lymphocytes (the two major airway cell populations) to be infected by hantaviruses $[12,13,15]$. The results from the current study showed an inverse relationship between the numbers of CTLs and Th cells and viral load, suggesting a beneficial role for $\mathrm{T}$ cells in hantavirus clearance. Based on our data, we could not show any relation between pulmonary viral load and disease severity. Nevertheless, such a relation cannot be excluded and an earlier BAL sampling could, speculatively, have revealed different results.

The study design with bronchoscopy at one single time point is a limitation of the current study. Serial, and earlier, BAL sampling would have given additional information about the time kinetics of the relation between the viral and immunological responses in the lungs. However, this was not feasible, as earlier bronchoscopy was deemed an unacceptable risk due to thrombocytopenia and risk for pulmonary bleeding.

The major strength of the current study is that lymphocyte subsets, viral load, and markers for cytotoxic activity have been investigated simultaneously in the lungs of patients with acute hantavirus infection, resulting in the unique possibility to evaluate the associations between these aspects.

In conclusion, the magnitude of the cytotoxic effector response may determine disease severity in patients with hantavirus infection. Whilst immunomodulatory treatment has not 
yet been proven to be successful [38], the present results may give valuable insights into the pathogenesis of hantavirus infections and, thereby, open up possibilities to develop new treatments.

Acknowledgments We are grateful to the patients and controls for their participation in the study, and thank the personnel at the Departments of Infectious Diseases and Respiratory Medicine \& Allergy, University Hospital, Umeå, for their assistance.

Compliance with ethical standards The study was approved by the regional ethical review board at Umeå University (number 07-162 M). Participants were treated according to the 1964 declaration of Helsinki and its later amendments. All participants gave written informed consent before study inclusion.

Funding This work was supported by grants from the Swedish HeartLung Foundation (grants 20080485 and 20100192), the County Councils of Northern Sweden (grants 296301 and 378271), and the County Council of Västerbotten and Medical Faculty of Umeå University (grant 216851).

Conflict of interest The authors report no conflict of interests.

Open Access This article is distributed under the terms of the Creative Commons Attribution 4.0 International License (http:// creativecommons.org/licenses/by/4.0/), which permits unrestricted use, distribution, and reproduction in any medium, provided you give appropriate credit to the original author(s) and the source, provide a link to the Creative Commons license, and indicate if changes were made.

\section{References}

1. Vaheri A, Strandin T, Hepojoki J et al (2013) Uncovering the mysteries of hantavirus infections. Nat Rev Microbiol 11:539-550

2. Castillo C, Naranjo J, Sepúlveda A, Ossa G, Levy H (2001) Hantavirus pulmonary syndrome due to Andes virus in Temuco, Chile: clinical experience with 16 adults. Chest 120:548-554

3. Duchin JS, Koster FT, Peters CJ et al (1994) Hantavirus pulmonary syndrome: a clinical description of 17 patients with a newly recognized disease. The Hantavirus Study Group. N Engl J Med 330: 949-955

4. Vapalahti O, Mustonen J, Lundkvist Å, Henttonen H, Plyusnin A, Vaheri A (2003) Hantavirus infections in Europe. Lancet Infect Dis 3:653-661

5. Rasmuson J, Pourazar J, Linderholm M, Sandström T, Blomberg A, Ahlm C (2011) Presence of activated airway T lymphocytes in human puumala hantavirus disease. Chest 140:715-722

6. Rasmuson J, Lindqvist P, Sörensen K, Hedström M, Blomberg A, Ahlm C (2013) Cardiopulmonary involvement in Puumala hantavirus infection. BMC Infect Dis 13:501

7. Pettersson L, Thunberg T, Rocklöv J, Klingström J, Evander M, Ahlm C (2014) Viral load and humoral immune response in association with disease severity in Puumala hantavirus-infected patientsimplications for treatment. Clin Microbiol Infect 20:235-241

8. Hayasaka D, Maeda K, Ennis FA, Terajima M (2007) Increased permeability of human endothelial cell line EA.Hy926 induced by hantavirus-specific cytotoxic T lymphocytes. Virus Res 123:120-127

9. Kilpatrick ED, Terajima M, Koster FT, Catalina MD, Cruz J, Ennis FA (2004) Role of specific CD8+ T cells in the severity of a fulminant zoonotic viral hemorrhagic fever, hantavirus pulmonary syndrome. J Immunol 172:3297-3304

10. Lindgren T, Ahlm C, Mohamed N, Evander M, Ljunggren HG, Björkström NK (2011) Longitudinal analysis of the human T cell response during acute hantavirus infection. J Virol 85:1025210260

11. Björkström NK, Lindgren T, Stoltz M et al (2011) Rapid expansion and long-term persistence of elevated NK cell numbers in humans infected with hantavirus. J Exp Med 208:13-21

12. Rasmuson J, Andersson C, Norrman E, Haney M, Evander M, Ahlm C (2011) Time to revise the paradigm of hantavirus syndromes? Hantavirus pulmonary syndrome caused by European hantavirus. Eur J Clin Microbiol Infect Dis 30:685-690

13. Zaki SR, Greer PW, Coffield LM et al (1995) Hantavirus pulmonary syndrome. Pathogenesis of an emerging infectious disease. Am J Pathol 146:552-579

14. Grankvist O, Juto P, Settergren B et al (1992) Detection of nephropathia epidemica virus RNA in patient samples using a nested primer-based polymerase chain reaction. J Infect Dis 165: 934-937

15. Gizzi M, Delaere B, Weynand B et al (2013) Another case of "European hantavirus pulmonary syndrome" with severe lung, prior to kidney, involvement, and diagnosed by viral inclusions in lung macrophages. Eur J Clin Microbiol Infect Dis 32:1341-1345

16. Nuovo GJ, Simsir A, Steigbigel RT, Kuschner M (1996) Analysis of fatal pulmonary hantaviral infection in New York by reverse transcriptase in situ polymerase chain reaction. Am J Pathol 148: 685-692

17. Salvi S, Blomberg A, Rudell B et al (1999) Acute inflammatory responses in the airways and peripheral blood after short-term exposure to diesel exhaust in healthy human volunteers. Am J Respir Crit Care Med 159:702-709

18. Evander M, Eriksson I, Pettersson L et al (2007) Puumala hantavirus viremia diagnosed by real-time reverse transcriptase PCR using samples from patients with hemorrhagic fever and renal syndrome. J Clin Microbiol 45:2491-2497

19. Linderholm M, Bjermer L, Juto P et al (1993) Local host response in the lower respiratory tract in nephropathia epidemica. Scand J Infect Dis 25:639-646

20. Salgado FJ, Lojo J, Fernández-Alonso CM, Viñuela J, Cordero OJ, Nogueira M (2002) Interleukin-dependent modulation of HLA-DR expression on CD4and CD8 activated T cells. Immunol Cell Biol 80:138-147

21. Hammerbeck CD, Hooper JW (2011) T cells are not required for pathogenesis in the Syrian hamster model of hantavirus pulmonary syndrome. J Virol 85:9929-9944

22. Safronetz D, Prescott J, Feldmann F et al (2014) Pathophysiology of hantavirus pulmonary syndrome in rhesus macaques. Proc Natl Acad Sci U S A 111:7114-7119

23. Koivula TT, Tuulasvaara A, Hetemäki I et al (2014) Regulatory T cell response correlates with the severity of human hantavirus infection. J Infect 68:387-394

24. Hallin GW, Simpson SQ, Crowell RE et al (1996) Cardiopulmonary manifestations of hantavirus pulmonary syndrome. Crit Care Med 24:252-258

25. Chowdhury D, Lieberman J (2008) Death by a thousand cuts: granzyme pathways of programmed cell death. Annu Rev Immunol 26: $389-420$

26. Heidema J, Lukens MV, van Maren WW et al (2007) CD8+ T cell responses in bronchoalveolar lavage fluid and peripheral blood mononuclear cells of infants with severe primary respiratory syncytial virus infections. J Immunol 179:8410-8417

27. Braun M, Björkström NK, Gupta S et al (2014) NK cell activation in human hantavirus infection explained by virus-induced IL-15/ IL15Ralpha expression. PLoS Pathog 10, e1004521 
28. Klingström J, Hardestam J, Stoltz M et al (2006) Loss of cell membrane integrity in puumala hantavirus-infected patients correlates with levels of epithelial cell apoptosis and perforin. J Virol 80:8279-8282

29. Gupta S, Braun M, Tischler ND et al (2013) Hantavirus-infection confers resistance to cytotoxic lymphocyte-mediated apoptosis. PLoS Pathog 9, e1003272

30. Veiga-Parga T, Sehrawat S, Rouse BT (2013) Role of regulatory T cells during virus infection. Immunol Rev 255:182-196

31. Easterbrook JD, Zink MC, Klein SL (2007) Regulatory T cells enhance persistence of the zoonotic pathogen Seoul virus in its reservoir host. Proc Natl Acad Sci U S A 104:15502-15507

32. Lanteri MC, O'Brien KM, Purtha WE et al (2009) Tregs control the development of symptomatic West Nile virus infection in humans and mice. J Clin Invest 119:3266-3277

33. Lühn K, Simmons CP, Moran E et al (2007) Increased frequencies of CD4+ CD25(high) regulatory T cells in acute dengue infection. J Exp Med 204:979-985
34. Pagliari C, Quaresma JA, Fernandes ER et al (2014) Immunopathogenesis of dengue hemorrhagic fever: contribution to the study of human liver lesions. J Med Virol 86: 1193-1197

35. Schönrich G, Rang A, Lütteke N, Raftery MJ, Charbonnel N, Ulrich RG (2008) Hantavirus-induced immunity in rodent reservoirs and humans. Immunol Rev 225:163-189

36. Zhu LY, Chi LJ, Wang X, Zhou H (2009) Reduced circulating CD4+CD25+ cell populations in haemorrhagic fever with renal syndrome. Clin Exp Immunol 156:88-96

37. Safronetz D, Zivcec M, Lacasse R et al (2011) Pathogenesis and host response in Syrian hamsters following intranasal infection with Andes virus. PLoS Pathog 7, e1002426

38. Vial PA, Valdivieso F, Ferres M et al (2013) High-dose intravenous methylprednisolone for hantavirus cardiopulmonary syndrome in Chile: a double-blind, randomized controlled clinical trial. Clin Infect Dis 57:943-951 